slidings from their truths. At the same time, he would be a bold man who would therefore label Christians, fireworshippers, Manichæans or Mormons, let alone Muslims, as Hindus. It may well be admitted that it would have saved a great deal of trouble to Census authorities if aboriginal tribes had all been included as Hindus ; it must indeed be admitted that a nice discrimination of the point at which they become Hindu is difficult in many tribes which have sophisticated sections of their population entirely Hinduized while other sections remain primitive in belief and practice.

Yet the distinction which $\mathrm{Mr}$. Elwin would apparently like to make between aboriginals and nonaboriginals is no easier to draw on racial or on cultural lines, and in the pursuit of truth in any event difficulty of attainment is neither here nor there. Mr. Elwin himself might just as fairly be suspected of a political or communal motive in advocating the return of aboriginal tribes as Hindus, as the Census officers are so suspected by him for trying to distinguish them from Hindus. It may be admitted that an entirely satisfactory criterion of Hinduism has not yet been found, but persons who do not observe caste, who disregard the religious authority of Brahmans, who do not hold the doctrine of karma can with difficulty be regarded as Hindus at all. One writer at the recent census of India-Mr. Webb, Census superintendent of Rajputana and author of "These Ten Years"-goes so far as to make untouchability actually the test of Hinduism in the case of tribes doubtfully within its pale. The Chamar, he says, is untouchable because he deals in cowhide and the flaying of cows, in pursuits, that is, defiling to a Hindu ; the Bhil follows practices just as repugnant to a good Hindu, but he is not untouchable; this can only be because it is recognized that since he is not a Hindu, those practices do not put him beyond the pale of decent society. The contention has some force, even though many Bhils are undoubtedly Hindus.

The amazing statement, again, that the creation of Excluded and Partially Excluded Areas "was largely the work of a distinguished anthropologist at the Round Table Conference", even if it contains any portion of the truth, which may well be doubted, is very far indeed from being the whole truth. The areas referred to were administered under special regulations long before the Round Table Conference was even conceived of, and their so-called "creation" was a natural and, as administration officers saw it, an almost inevitable development in the process of applying the reforms to Indian political life. Anyone interested in pursuing the point might refer to Chapter 7 of Part ii of Vol. 1 of the Indian Statutory Commission's Report of 1930, and to Chapter 2 of Part iii in Vol. 2.

There are other very questionable statements of a similar kind. In one case a writer is quoted as expressing an opinion, and then taken to task for giving information. But what he gave was a statement not of fact but of an opinion derived, perhaps quite legitimately, from such information as he did succeed in obtaining. The adjective "Tylorian" is used as a derogatory epithet-and so forth. All of which is a great pity, for Mr. Elwin has something to say, and we agree with him entirely in his statement that "truth in anthropology demands a scrupulous adherence to the highest rules and standards in fieldwork". No doubt presidential addresses are not fieldwork, but that is no ground for any relaxation in them of the high rules and standards of a scientific approach, nor for the imputing of disingenuous motives to workers whose outlook and views prove unpalatable to the temporary occupant of the chair. J. H. HutTon.

\section{PARASITIC DISEASES OF MAN IN RELATION TO THE WAR}

TIVE addresses given to a conference on parasitic diseases held by the New York Academy of Sciences in March 1943 have been published (Ann. New York Acad. Sci., 44, Art. 3, 189-262 ; 1943). In his introductory address, Prof. H. W. Stunkard points out that the study of animal parasites is no longer an academic one, because the diseases they cause constitute one of the most pressing problems of to-day and to-morrow. The gravity of the problem is increased by the dispersal of American (and, we would add, other) troops to all parts of the world, where they are acquiring parasitic diseases. These troops may, both now and after the War, bring back to their home countries parasites not normally prevalent there. Not all these parasites will be able. to spread in these home countries, either because the local climatic and other conditions are not favourable to them or because the intermediate hosts necessary for the completion of their life-histories do not exist. But it is known that some parasites have been able, to acquire new intermediate and definitive hosts in countries to which they have been transported. Prof. Stunkard gives as an example of this the sheep. liver fluke, and he considers the possibility that the human schistosomes may, for example, acquire the ability to develop in some snail in America. The risk of the introduction of new parasites into the home countries is real enough to require energetic action. We in Great Britain, with much colonial and tropical experience to guide us, have been always aware of it ; and it is evident that the United States' authorities have also taken the problem in hand.

Already during this War parasites have done appreciable harm to both Allied and Axis troops. Trichiniasis has put out of action at least one battalion of German troops in Norway (Bull. War Med., 3, 236 ; 1942), and German commando and other troops have suffered from this disease on their Eastern front. We know also something of the precautions taken by the Germans to protect their Afrika Korps from disease in Egypt and the tropics. Their problems would seem to be now solved for them by the removal by the Allies of all possibility of the entry of Axis troops into the tropics.

For the Allies, however, these problems increase as their victories extend. Prof. Stunkard states that it has been reported that the United States' defeat at Bataan was due as much to the malarial parasite as to other causes. He estimates that a million or more United States troops may acquire parasites and that their fighting efficiency may be proportionately reduced. Dr. Coggeshall, dealing with current and post-war problems associated with human Protozoan diseases, says that United States troops are already acquiring Protozoan infections from native reservoirs at an alarming rate. Amcebic dysentery and malaria are the chief dangers in this field, although other parasites (for example, the trypanosomes) must not be forgotten. Malaria, which is one of the major enemies of both sides in war, can persist in man for 
years, especially if it is quartan malaria. Dr. Coggeshall cites the case of a Greek who acquired quartan malaria in Greece and, after thirty-seven years in Denver, gave his blood for blood transfusion and communicated quartan malaria to the recipient of it. Dr. Matheson, at the same meeting, recorded the transmission of the parasite of malignant tertian malaria (Plasmodium falciparum) to a sixyear-old child in Ithaca, N.Y., through receiving a blood transfusion from her father, who had never shown symptoms of the infection. E. L. Lozner and L. R. Newhouser (Amer. J. Med. Sci., 206, 141-146; 1943 ; and Bull. War Med., 4, 353; 1944) conclude that there is no likelihood of the transmission of malaria by blood plasma used for transfusions. They did, however, transmit malaria to two out of 35 recipients of plasma taken from patients infected with either quartan or malignant tertian malaria, but the plasma given to these two cases had been preserved for only one day in the liquid state. Malaria was not transmitted when the plasma of malarial patients was preserved in the liquid state at room temperature for two weeks, or when it was either frozen and then stored at $-20^{\circ} \mathrm{C}$. or dried from the frozen state.

The control of the vectors of malaria is another important problem. Anopheles quadrimaculatus, which can transmit all three human species of the malarial parasite, is the chief vector of malaria in the United States and is abundant as far north as the Canadian border. The corresponding malarial problem in Great Britain has been considered by Sir A. McNalty (NATuRE, April 17, 1943, p. 440), and the British species of mosquitoes and their control are dealt with by Lieut.-Colonel Sinton and P. G. Shute (Min. of Health Mem. Med., 238; 1943). J. F. Marshall (NATURe, 149, 568; 1942) and Dr. A. B. Williamson and J. F. Marshall (Brit. Med.J., Sept. 1 1, 1943, p. 332) have studied the breeding of mosquitoes in wartime static-water tanks in Britain. The damage,that malaria can do to armies in the field is indicated by the figures given by Dr. T. T. Mackie in his address in the American symposium on the clinical features of parasitic diseases. To give only one example of these, Mackie says that the French force of $120,000 \mathrm{men}$ in Macedonia in 1916 was reduced by malaria to an effective field force of only 30,000 , that the British Macedonian force had 30,000 malaria cases in 1916 and 70,000 in 1917, and that the Germans had similar losses; so that Plasmodium alone immobilized these armies.

Problems of control among large numbers of people are difficult enough in times of peace. These diffculties are increased in war-time, and added difficulty is introduced by rapid transport. The aeroplane itself may introduce infected hosts and vectors of all kinds of diseases (Jackson, W. P., Virginia Med. Monthly, 69, 29; 1942; and Bull. War Med., 3, 629; 1943). Coggeshall points out that practically all the foreign air traffic to the United States, except that to and from Great Britain, originates in the tropics, where airports are usually in places in which sanitary measures are inadequate or absent; these airports are also surrounded by native villages the inhabitants of which are used as labourers and who are infected. The risks involved are exemplified by the accidental introduction in 1930 of Anopheles gambioe into South America; this was followed by an epidemic of malaria which caused 100,000 cases and a minimum of 14,000 deaths. The insect was eradicated by the joint efforts of the Brazilian Government and the Rockefeller Foundation (Soper, F. L., and Wilson,
D. B., J. Nat. Malaria Soc., 1, 5; 1942 and The Lancet, Jan. 22, 1944, p. 120). Failure to perform this difficult feat might have resulted in disaster to all the tropical areas of the western hemisphere.

Coggeshall's further remarks on the virulent malaria and dysentery seen by him among Poles coming out of Russia to Persia in 1942, and the risk of their spreading these diseases to India, East Africa and other places to which they were dispersed, make clear the risk inherent in mass migrations of peoples, especially if, as is scarcely avoidable in war. time, they are in poor health. and encounter strains of a parasite to which they are not accustomed. Such strains produced, after the War of 1914-18, secondary epidemics of malaria in England, Germany (6,000 cases) and Russia ( 3 million cases west of the Urals, half the population of Georgia and the deaths of two-thirds of the population in villages near Tiflis). These figures recall the ravages of typhus and plague, and remind us that the vectors of disease caused by bacteria and viruses may also be carried by aeroplane. This aspect of the problem was dealt with in an address by Dr. R. Matheson on "Arthropods as Vectors of Human Diseases". So far as malaria is concerned, we should do well, says the Lancet (March 18, 1944, p. 380), to be warned by the experience of France, where malaria, introduced in 1939 by infected Spanish refugees, has persisted since that date in the Canet and Saint-Cyprien regions of the Pyrénées-orientales.

That the French National Committee of Liberation is already tackling the problems of the parasites, as well as those of other diseases, in the French African Colonies, is indicated by a special medical section of the Brazzaville Conference (The Lancet, April 1, $1944, p .440$ ). The proposals made include the creation of large mobile units to seek out and treat illness and deal with problems of sanitation, and the establishment of a central institute of hygiene and research and, after the War, a medical school and an international bureau of public health.

Dr. N. R. Stoll, taking as the title of his address "Changed Viewpoints in Helminthic Disease : World War I vs. World War II', gives a summary of modern views on the control of hookworms, Trichinella, tapeworms, the flukes of the Orient and other helminth parasites. $\mathrm{He}$ outlines our changed views on the epidemiology of diseases caused by this kind of parasite and on human resistance and immunity to them. Stoll quotes Leiper's list of facts (Brit. Med. $J$., July 19, 1924, p. 110) about the helminth which the public health worker should remember. Helminths do not multiply within the human body; their eggs or embryos have to leave the human body and are not infective to man when they leave him, but have to undergo first a development outside man, either in the outside world or in an intermediate host; the environment necessary for this development varies with different species; the helminth enters man by the mouth or by penetration of the skin and many species then have to make extensive journeys inside the human body; few helminths are specific to man and their spread can be prevented by breaking the life-cycle. The knowledge gained about helminth parasites during recent years should, says Leiper, enable us eventually to eradicate helminth infestations of man, if it is properly used. A big "if", some would say; but the task is possible. Under the conditions which we may expect after the War, it will indeed be formidable.

G. LAPAGE. 